\title{
SURFACE TREATMENT OF HEAT-TREATED CAST MAGNESIUM AND ALUMINIUM ALLOYS
}

\author{
OBDELAVA POVRŠINE TOPLOTNO OBDELANIH MAGNEZIJEVIH \\ IN ALUMINIJEVIH LIVNIH ZLITIN
}

\author{
Tomasz Tański, Maciej Wiśniowski, Wiktor Matysiak, Marcin Staszuk, Radosłav Szklarek \\ Silesian University of Technology, Institute of Engineering Materials and Biomaterials, Konarskiego Str. 18A, 44-100 Gliwice, Poland \\ tomasz.tanski@polsl.pl \\ Prejem rokopisa - received: 2015-06-26; sprejem za objavo - accepted for publication: 2015-10-12
}

doi:10.17222/mit.2015.132

\begin{abstract}
Modern coating systems deposited on surface layers of structural light materials are currently one of the most important issues in up-to-date material engineering, where vacuum deposition techniques are often used to improve the mechanical and functional properties of produced surface layers. Presented in this paper are gradient and monolithic coating types: Ti/Ti(C,N)/CrN, $\mathrm{Ti} / \mathrm{Ti}(\mathrm{C}, \mathrm{N}) /(\mathrm{Ti}, \mathrm{Al}) \mathrm{N}, \mathrm{Ti} /(\mathrm{Ti}, \mathrm{Si}) \mathrm{N} /(\mathrm{Ti}, \mathrm{Si}) \mathrm{N}, \mathrm{Cr} / \mathrm{CrN} / \mathrm{CrN}, \mathrm{Cr} / \mathrm{CrN} / \mathrm{TiN}$ and Ti/DLC/DLC deposited onto magnesium and aluminium alloy substrates with the cathodic-arc-evaporation method (Arc PVD) and plasma-assisted process (PA CVD). Additionally, a thin metallic layer - in micrometers- $(\mathrm{Cr}$ and $\mathrm{Ti}$ ) was deposited prior to the deposition of the final gradient coating to improve its adhesion to the substrate. This work presents the investigation results concerning the obtained surface-layer microstructures and mechanical properties of the obtained bi-layer coatings (gradient/multicompound) deposited onto light-alloy substrates using the chosen PVD and CVD methods, especially to meet the requirements needed for light-metal substrates - low temperature and duration. The structure investigations of the deposited coating were performed using a scanning electron microscopy (SEM) and glow discharge optical emission spectrometry (GDOES); the mechanical and functional properties were examined using the ball-on-disk method for the wear-resistance determination, and microhardness tests were performed for the functional usability of the coatings. The main finding is that the fracture morphology is characterized by a lack of columnar structures in the obtained coatings. The metallographic examinations carried out proved that the coatings were deposited uniformly over the whole sample, onto the investigated substrate materials; the measured thickness is characteristic for the produced coating type.It was also found that the particular layers adhere tightly to each other and to the light-metal substrate. The investigation results of the up-to-date PVD methods, together with light alloys, led to obtaining new applications, especially in the automobile and aviation industries.
\end{abstract}

Keywords: light alloys, PVD, CVD, structure, properties

Moderni sistemi nanosov na površinskih plasteh lahkih konstrukcijskih materialov so eden od najpomembnejših izzivov v inženiringu materialov, kjer se za izboljšanje mehanskih in funkcionalnih lastnosti plasti na površini pogosto uporabljajo tehnike vakuumske depozicije. V članku so predstavljeni gradientni in monolitni nanosi vrst: $\mathrm{Ti} / \mathrm{Ti}(\mathrm{C}, \mathrm{N}) / \mathrm{CrN}, \mathrm{Ti} / \mathrm{Ti}(\mathrm{C}, \mathrm{N}) /(\mathrm{Ti}, \mathrm{Al}) \mathrm{N}$, $\mathrm{Ti} /(\mathrm{Ti}, \mathrm{Si}) \mathrm{N} /(\mathrm{Ti}, \mathrm{Si}) \mathrm{N}, \mathrm{Cr} / \mathrm{CrN} / \mathrm{CrN}, \mathrm{Cr} / \mathrm{CrN} / \mathrm{TiN}$ in Ti/DLC/DLC ki so bili nanešeni z metodo katodnega izparevanja v obloku (Arc PVD) in s plazemskim postopkom (PA CVD). Dodatno je bila nanešena tanka kovinska plast (Cr in Ti), debelina v mikrometrih, in sicer pred nanosom končnega gradientnega nanosa, da bi se izboljšala njegova oprijemljivost na podlago. Članek predstavlja rezultate raziskave mikrostrukture površinskega nanosa in mehanske lastnosti dvoplastnega nanosa (gradient/multicompound), nanešenega na podlago iz lahke zlitine, s pomočjo izbranih metod PVD in CVD, da bi zagotovili zahtevam podlage iz lahke kovine - nizka temperatura in kratko trajanje. Preiskave zgradbe nanosa so bile izvedene s pomočjo vrstične elektronske mikroskopije (SEM) in z razelektritveno optično emisijsko spektrometrijo (GDOES), medtem ko so bile mehanske in funkcionalne lastnosti, preiskane z uporabo metode kroglica na plošči za določanje obrabne odpornosti ter mikrotrdote za funkcionalno uporabnost nanosov. Glavna ugotovitev je, da v morfologiji preloma nanosov ni stebraste zgradbe. Izvedene metalografske preiskave so pokazale, da so nanosi enakomerno nanešeni po vsej površini preiskovane podlage, izmerjene debeline so značilne za to vrsto nanosov in ugotovljeno je tudi, da se posamezni nanosi med seboj tesno stikajo, tudi s podlago iz lahke kovine. Rezultati raziskav kažejo, da uporaba sodobnih PVD metod, skupaj z lahkimi zlitinami, omogoča nove aplikacije, posebno $\mathrm{v}$ avtomobilski in letalski industriji.

Ključne besede: lahke zlitine, PVD, CVD, struktura, lastnosti

\section{INTRODUCTION}

Dynamic industry development introduces an escalation of requirements concerning new needs and working conditions, which facilitateand direct theprogress within material engineering, especially in the case of fabrication and examination of new materials. ${ }^{1-3}$ Properties of many products and their elements depend not only on the possibility of transmitting mechanical loads through the whole active intersection or the material's physical and chemical properties, but also on the structure and properties of the surface layer. The use of surface layers, fulfill- ing thehigh requirements withsoft and cheap cores, is a great way of reducing expenses. A wide range of available layers and ways of theirmodification facilitate the design of thebest combination of core and layer properties possible. Modern surface-engineering techniques including the use of a corrosion- and abrasive-resistant hard material, despite the maintenance of accurate properties, should allow usto combine esthetic values and ecological production. ${ }^{3}$

With many available techniques of improving engineering materials, the physical vapordeposition (PVD), 
chemical vapordeposition (CVD) and hybrid methods (which enable a full control of thechemical composition, structure and properties using characteristics of particular methods like CVD, PVD and conventional thermochemical treatments - thermal spraying + heat treatment, nitriding or cyaniding + pulsed-laser deposition (PLD), autocatalytic layer deposition + plasma-assisted processing) are essential. ${ }^{4-20}$ Anotherimportant surface engineering technology, applied inlight-alloy processing, is the laser treatment including remelting and alloying. ${ }^{3}$ These techniques allow us to make layers with special properties (high hardness and tribological resistance combined with constant substrate properties) and the thickness in a range from tenths of a millimeter to even a few millimeter scan be achieved. A layer obtained with the laser-alloying or remelting technique has a different structure and properties than those of the base or the alloying elements. ${ }^{3}$ The morphology of a quasi-composite layer is homogeneous and exhibits a proper dispersion of the alloying elements into the whole depth except for a very thin diffusion-saturation layer.

The aim of this research was to obtain a hard coat for a soft core - such a material can resist different amounts of load (depending on many factors) because of the coating and thanks to the soft core, the internal forces are transferred and reduced inside. In some cases, the corrosion resistance is also observed, which is very desirable. An important part of the investigationdone on the mate- rial was the examination of the structures and mechanical properties of gradient/monolithic coatings deposited with the PVD and CVD methods onto magnesium and aluminum casting alloys after the heat treatment.5,9,16,18

\section{EXPERIMENTAL PART}

The materials used for the investigation includedcast magnesium and aluminium alloys, whosechemical compositions are presented in Table 1. The deposition of coatings $\mathrm{Ti} / \mathrm{Ti}(\mathrm{C}, \mathrm{N}) / \mathrm{CrN}, \quad \mathrm{Ti} / \mathrm{Ti}(\mathrm{C}, \mathrm{N}) /(\mathrm{Ti}, \mathrm{Al}) \mathrm{N}$, $\mathrm{Ti} /(\mathrm{Ti}, \mathrm{Si}) \mathrm{N} /(\mathrm{Ti}, \mathrm{Si}) \mathrm{N}, \mathrm{Cr} / \mathrm{CrN} / \mathrm{CrN}, \mathrm{Cr} / \mathrm{CrN} / \mathrm{TiN}$ and Ti/DLC/DLC was made within a device based on the CAE PVD method in anatmosphere of $\mathrm{Ar}, \mathrm{N}_{2}$ and $\mathrm{C}_{2} \mathrm{H}_{2}$; moreover, the DLC coating wasdeposited using acetylene $\left(\mathrm{C}_{2} \mathrm{H}_{2}\right)$ as the precursor and was produced with the PA CVD method. A gradient change in thechemical composition ofthe PVD coatings' cross-sections was achieved by changing the proportion of the reactive-gas dose or a variation in thearc-source current. The DLC coating was characterized byavariation in the silicon (Me) concentration, demonstrating that a gradient layer wasobtained. Silicon was supplied to the furnace chamber from the gas phase, Ti/a-C:H-Me/a-C:H. Cathodes containing pure metals $(\mathrm{Cr}, \mathrm{Ti})$ and alloys of $\mathrm{TiAl}$ and TiSi (50:50 \% amount fractions) were used for the deposition of the coatings. The diameter of the used cathodes was $65 \mathrm{~mm}$. The temperature was controlled with

Table 1: Chemical compositions oftheinvestigated alloys

Tabela 1: Kemijska sestava preiskovanih zlitin

\begin{tabular}{|c|c|c|c|c|c|c|c|c|}
\hline Type of material & \multicolumn{5}{|c|}{ Mass concentration of the elements, in mass fractions $(w / \%)$} \\
\hline & $\mathrm{Al}$ & $\mathrm{Zn}$ & $\mathrm{Mn}$ & $\mathrm{Si}$ & $\mathrm{Mg}$ & $\mathrm{Fe}$ & $\mathrm{Cu}$ & $\mathrm{Rest}$ \\
\hline Magnesium alloy - AZ91 & 9.09 & 0.77 & 0.21 & 0.04 & 89.8 & 0.011 & - & 0.079 \\
\hline Magnesium alloy - AZ61 & 5.92 & 0.49 & 0.15 & 0.04 & 93.3 & 0.007 & - & 0.093 \\
\hline Aluminium alloy - AlSi9Cu4 & 85.4 & 0.05 & 0.01 & 9.27 & 0.28 & 0.34 & 4.64 & 0.01 \\
\hline Aluminium alloy - AlSi9Cu & 88.86 & 0.16 & 0.37 & 9.1 & 0.27 & 0.18 & 1.05 & 0.01 \\
\hline
\end{tabular}

Table 2: Deposition parameters of the investigated coatings

Tabela 2: Parametri nanašanja preiskovanih nanosov

\begin{tabular}{|c|c|c|c|c|c|c|}
\hline \multirow{3}{*}{ Coating parameters } & \multicolumn{6}{|c|}{ Type of the achieved coating and the applied coating technique } \\
\hline & \multicolumn{5}{|c|}{ PVD } & CVD \\
\hline & \begin{tabular}{|c|} 
Ti/Ti(C,N)-gra- \\
dient/CrN
\end{tabular} & \begin{tabular}{|l|}
$\mathrm{Ti} / \mathrm{Ti}(\mathrm{C}, \mathrm{N})$-gra- \\
dient/(Ti,Al)N
\end{tabular} & $\begin{array}{c}\mathrm{Cr} / \mathrm{CrN} \text {-gradi- } \\
\text { ent/CrN }\end{array}$ & $\begin{array}{c}\mathrm{Cr} / \mathrm{CrN} \text {-gradi- } \\
\text { ent/TiN }\end{array}$ & $\begin{array}{c}\mathrm{Ti} /(\mathrm{Ti}, \mathrm{Si}) \mathrm{N}-\mathrm{grad} \\
\text { ient/(Ti,Si)N }\end{array}$ & $\begin{array}{l}\text { Ti/DLC-gradi- } \\
\text { ent/DLC }\end{array}$ \\
\hline Base pressure $(\mathrm{Pa})$ & $5 \times 10^{-3}$ & $5 \times 10^{-3}$ & $5 \times 10^{-3}$ & $5 \times 10^{-3}$ & $5 \times 10^{-3}$ & $1 \times 10^{-3}$ \\
\hline Working pressure $(\mathrm{Pa})$ & $0.9 / 1.1-1.9 / 2.2$ & $0.9 / 1.1-1.9 / 2.8$ & $1.0 / 1.4-2.3 / 2.2$ & $1.0 / 1.4-2.3 / 2.2$ & $0.89 / 1.5-2.9 / 2.9$ & 2 \\
\hline \multirow{3}{*}{ Argon flow rate $(\mathrm{sccm})$} & $80 *$ & $80 *$ & $80 *$ & $80 *$ & $80 *$ & $80 *$ \\
\hline & $10 * *$ & $10 * *$ & $80 * *$ & $80 * *$ & $20 * *$ & - \\
\hline & $10 * * *$ & $10 * * *$ & $20 * * *$ & $20 * * *$ & $20 * * *$ & - \\
\hline \multirow{2}{*}{ Nitrogen flow rate $(\mathrm{sccm})$} & $225 \rightarrow 0 * *$ & $0 \rightarrow 225^{* *}$ & $0 \rightarrow 250 * *$ & $0 \rightarrow 250 * *$ & $0 \rightarrow 300 * *$ & - \\
\hline & $250 * * *$ & $350 * * *$ & $250 * * *$ & $250 * * *$ & & \\
\hline Acetylene flow rate $(\mathrm{sccm})$ & $0 \rightarrow 170 * *$ & $140 \rightarrow 0 * *$ & - & - & & 230 \\
\hline \multirow{3}{*}{ Substrate bias voltage (V) } & $70 *$ & $70 *$ & $60 *$ & $60 *$ & $70 *$ & 500 \\
\hline & $70 * *$ & $70 * *$ & $60 * *$ & $60 * *$ & $100 * *$ & \\
\hline & $60 * * *$ & $70 * * *$ & $60 * * *$ & $100 * * *$ & $100 * * *$ & \\
\hline Target current (A) & 60 & 60 & 60 & 60 & 60 & - \\
\hline Process temperature $\left({ }^{\circ} \mathrm{C}\right)$ & $<150$ & $<150$ & $<150$ & $<150$ & $<150$ & $<180$ \\
\hline
\end{tabular}

*during the metallic-layer deposition, $* *$ during the gradient-layer deposition, $* * *$ during the ceramic-layer deposition 
thermocouples. To improve the adhesion of the coatings, a transition $\mathrm{Cr}$, Ti interlayer was deposited. The working pressure during the deposition process was $2-4 \mathrm{~Pa}$, depending on the coating type. The distance between the cathodes and the deposited substrates was $120 \mathrm{~mm}$. Just before the coating-deposition process, the specimens were prepared with the standard procedures of grinding, polishing and chemical cleaning using multi-stage washing in an ultrasonic cleaner and a cascade washer, then dried in hot air. The next step was ion etching in the chamber to clean the surfaces atthe atomic scale and to activate them. The parameters used were asubstrate-polarization voltage of $800 / 200 \mathrm{~V}$ and a period of $20 \mathrm{~min}$. The conditions of the coating deposition are presented in Table 2.

The investigations of the microstructures, micro-area qualitative and quantitative chemical compositionswere performed using a scanning electron microscope (SEM) ZEISS Supra 35. The cross-sectional atomic composition of the samples (coating and substrate) was obtained by using the glow discharge optical spectrometer GDOS750 QDP from Leco Instruments.

The microhardness tests of the coatings were made with a SHIMADZU DUH 202 ultra-microhardness tester. The measurements were made with a $10 \mathrm{mN}$ load, to eliminate the substrate influence on the coating hardness. Wear-resistance investigations were performed using the ball-on-disk method. A tungsten carbide ball with a diameter of $3 \mathrm{~mm}$ was used as the counter part. The tests were performed at room temperature overa defined time using the following test conditions: a load of $F_{\mathrm{n}}=$ $5 \mathrm{~N}$, a rotation of the disk of $200 \mathrm{~min}^{-1} 20.94 \mathrm{r} / \mathrm{s}$, a wear radius of $2.5 \mathrm{~mm}$ and a sliding speed of $0.05 \mathrm{~m} / \mathrm{s}$.

\section{RESULTS AND DISCUSSION}

In order to determine the structures and relationships between the type of substrate and the types of hybrid layers, the metallographic investigation was done under the

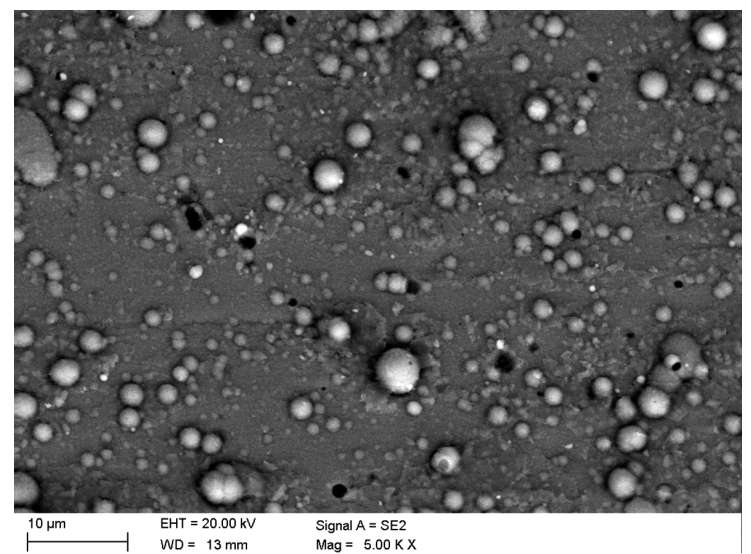

Figure 1: Surface topography of $\mathrm{Ti} / \mathrm{Ti}(\mathrm{C}, \mathrm{N}) / \mathrm{CrN}$ layer obtained on $\mathrm{AlSi}_{9} \mathrm{Cu}_{4}$ cast aluminum alloy

Slika 1: Topografija površine nanosa $\mathrm{Ti} / \mathrm{Ti}(\mathrm{C}, \mathrm{N}) / \mathrm{CrN}$ na $\mathrm{AlSi}_{9} \mathrm{Cu}_{4}$ aluminijevi livni zlitini technological conditions (the soft substrate - the gradient intermediate layer able to easily change the concentration of one or a few components between the base and the surface - and the external layer) of the cathodic-arc deposition, Arc-PVD, and plasma-assisted chemical vapor deposition, PA-CVD processes.

The layers obtained with the CAE-PVD technique are heterogeneous, as many drop-shaped micro-sized molecules exist in their structures. This fact leads to changes in the mechanical, physical and chemical properties of the examined layers (Figures 1 to 6). The biggest surface heterogeneity, in comparison to the other examined layer surfaces, is visible within the $\mathrm{Ti} / \mathrm{Ti}(\mathrm{C}, \mathrm{N}) /$ (Ti,Al)N and $\mathrm{Ti} / \mathrm{Ti}(\mathrm{C}, \mathrm{N}) / \mathrm{CrN}$ systems, in which a lot of precipitation of the evaporated, metal, clotty drops were identified (Figures 1 and 2). The occurrence of this morphological defect is related with the Arc-PVD process characteristics. Depending on the process parameters, including the kinetic energy transferred to the drops that are crashed due to the metallic base, and the type of the metal-vapor source used, particles varyingin shape and size are observed. It was confirmed that the clotty drops are spheroidal or irregular or they form agglomerates that often include a few equal drops (Figures 1 to $\mathbf{6}$ ). Moreover, characteristic hollows that form because of the clotty drops falling out, were observed after the PVD process wasfinished. On the basis of the metallographic observations it was confirmed that the hollows do not reach the surface. On the DLC layer obtained within the PACVD process fine drops, mostly spheroidal, were identified as well (Figure 5). The surface morphology of the DLC layer is different from that obtained with classical high-temperature CVD processes - no micro-gaps or wavy and globular-like surfaces were observed. The smallest amount of morphologic surface defects was obtained with the $\mathrm{Cr} / \mathrm{CrN} / \mathrm{TiN}$ layer (Figure 4).

A fractographic examination of magnesium- and aluminum-alloy samples with the applied layers, done with a scanning electron microscope, showed a sharp transi-

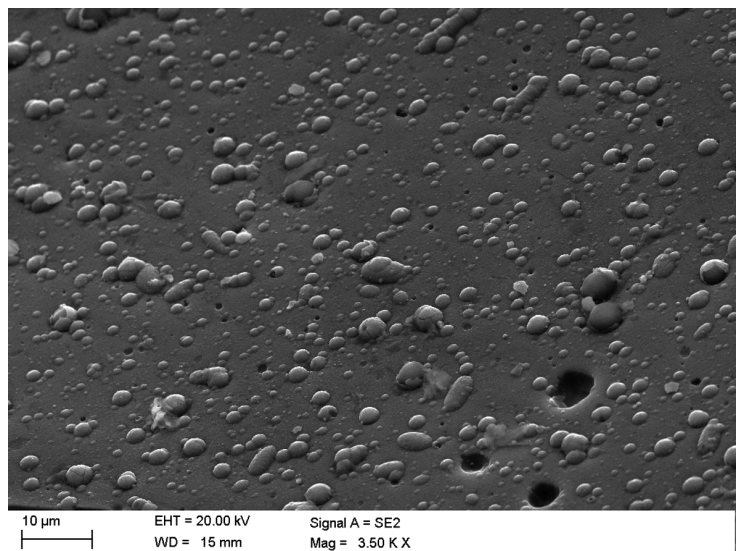

Figure 2: Surface topography of $\mathrm{Ti} / \mathrm{Ti}(\mathrm{C}, \mathrm{N}) /(\mathrm{Ti}, \mathrm{Al}) \mathrm{N}$ layer obtained on $\mathrm{MCMgAl6Zn} 1$ cast magnesium alloy

Slika 2: Topografija površine nanosa $\mathrm{Ti} / \mathrm{Ti}(\mathrm{C}, \mathrm{N}) /(\mathrm{Ti}, \mathrm{Al}) \mathrm{N}$ na $\mathrm{MCMgAl}_{6} \mathrm{Zn}_{1}$ livni magnezijevi zlitini 


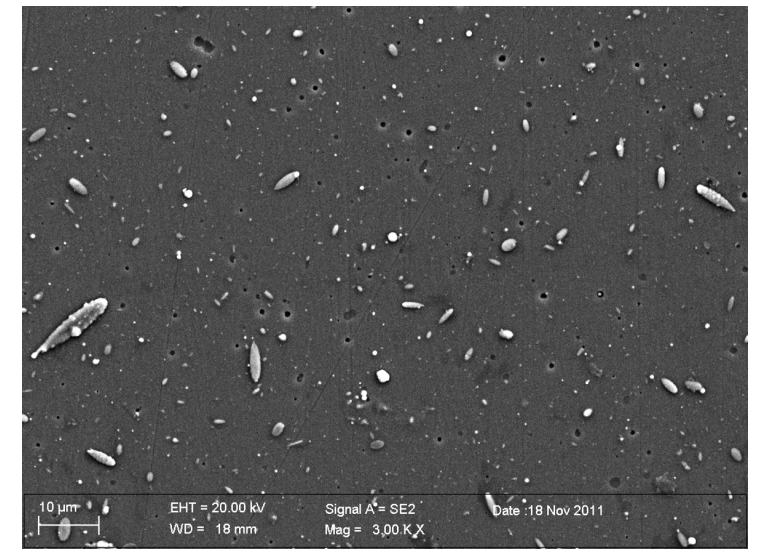

Figure 3: Surface topography of $\mathrm{Cr} / \mathrm{CrN} / \mathrm{CrN}$ layer obtained on $\mathrm{MCMgAl}_{9} \mathrm{Zn}_{1}$ cast magnesium alloy

Slika 3: Topografija površine nanosa $\mathrm{Cr} / \mathrm{CrN} / \mathrm{CrN}$ na $\mathrm{MCMgAl}_{9} \mathrm{Zn}_{1}$ livni magnezijevi zlitini

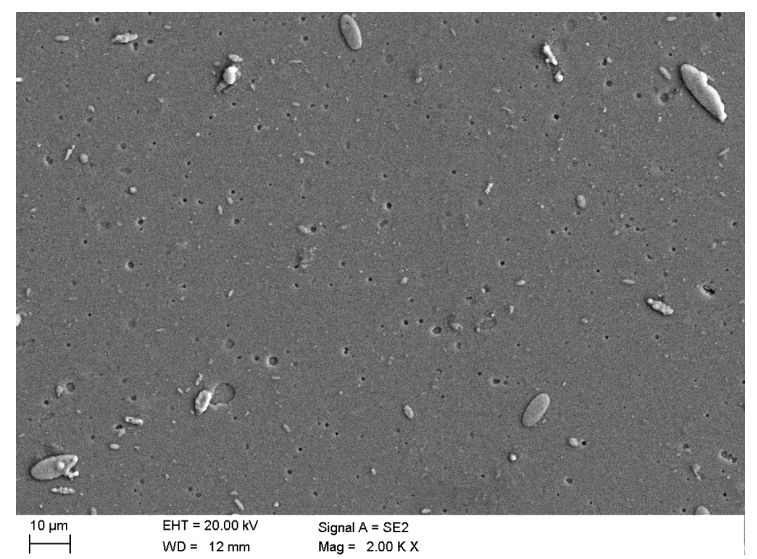

Figure 4: Surface topography of $\mathrm{Cr} / \mathrm{CrN} / \mathrm{TiN}$ layer obtained on $\mathrm{MCMgAl}{ }_{9} \mathrm{Zn}_{1}$ cast magnesium alloy

Slika 4: Topografija površine nanosa $\mathrm{Cr} / \mathrm{CrN} / \mathrm{TiN}$ na $\mathrm{MCMgAl}_{9} \mathrm{Zn}_{1}$ livni magnezijevi zlitini

tion zone between the base and the layer. The layers are compact in structure with no visible delamination or defects. They are placed uniformly and they adhere to the

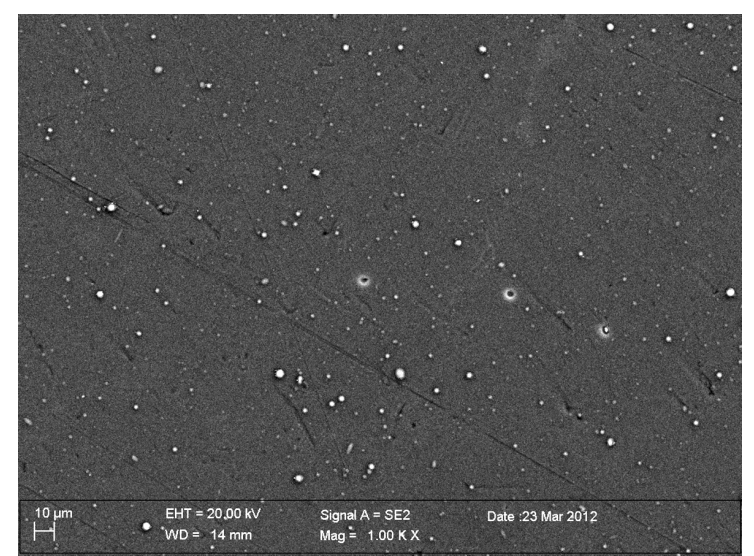

Figure 5: Surface topography of Ti/DLC/DLC layer obtained on $\mathrm{AlSi}_{9} \mathrm{Cu}_{1}$ cast aluminum alloy

Slika 5: Topografija površine nanosa Ti/DLC/DLC na $\mathrm{AlSi}_{9} \mathrm{Cu}_{1}$ livni aluminijevi zlitini

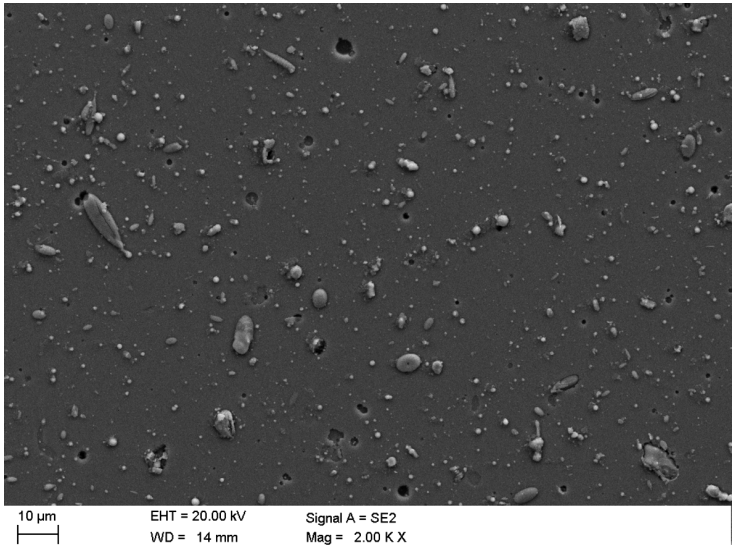

Figure 6: Surface topography of $\mathrm{Ti} /(\mathrm{Ti}, \mathrm{Si}) \mathrm{N} /(\mathrm{Ti}, \mathrm{Si}) \mathrm{N}$ layer obtained on $\mathrm{AlSi}_{9} \mathrm{Cu}_{1}$ cast aluminum alloy

Slika 6: Topografija površine nanosa $\mathrm{Ti} /(\mathrm{Ti}, \mathrm{Si}) \mathrm{N} /(\mathrm{Ti}, \mathrm{Si}) \mathrm{N}$ na $\mathrm{AlSi}_{9} \mathrm{Cu}_{1}$ livni aluminijevi zlitini

base hermetically (Figures 7 to 10). Observations of the fractures confirm that layers like $\mathrm{Ti} / \mathrm{Ti}(\mathrm{C}, \mathrm{N}) /(\mathrm{Ti}, \mathrm{Al}) \mathrm{N}$ and $\mathrm{Ti} / \mathrm{Ti}(\mathrm{C}, \mathrm{N}) / \mathrm{CrN}$ are laminar with a visible transition zone between the gradient and the anti-wear layers obtained with different metal-vapor sources (Figure 7). On the cross-section of the $\mathrm{Cr} / \mathrm{CrN} / \mathrm{CrN}, \mathrm{Ti} /(\mathrm{Ti}, \mathrm{Si}) \mathrm{N} /$ (Ti,Si)N layers, in which identical sets of chemical elements of gradient and anti-wear layers were used, no visible differences were observed (Figure 8). In addition, multi-layer carbon coats like Ti/DLC/DLC obtained with the CVD method, in which the gradient in the middle coating allows a variable silicon concentration, do not exhibit any visible transition zone between individual layers. Moreover, in the range of the thin adhesive layer (whose task is to improve the adhesion of the base and DLC layers) is was possible to identify a bright, continuous layer of titanium, which was also confirmed with theEDS spectrometry analysis (Figure 9). It was confirmed that the titanium nitride layer obtained with the $\mathrm{Cr} / \mathrm{CrN} / \mathrm{TiN}$ system has a close to columned rise character of crystallite that is characteristic for titanium

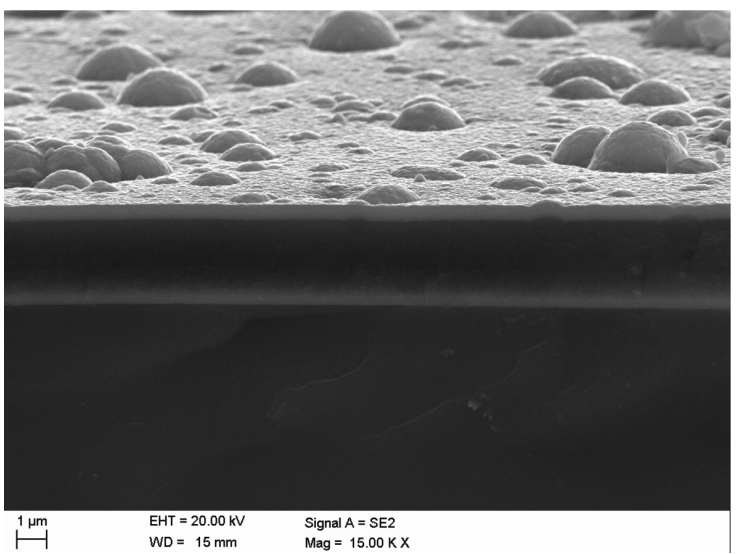

Figure 7: Fracture of $\mathrm{Ti} / \mathrm{Ti}(\mathrm{C}, \mathrm{N}) / \mathrm{CrN}$ layer obtained on $\mathrm{AlSi}_{9} \mathrm{Cu}_{4}$ cast aluminum alloy

Slika 7: Prelom nanosa $\mathrm{Ti} / \mathrm{Ti}(\mathrm{C}, \mathrm{N}) / \mathrm{CrN}$ na $\mathrm{AlSi}_{9} \mathrm{Cu}_{4}$ livni aluminijevi zlitini 


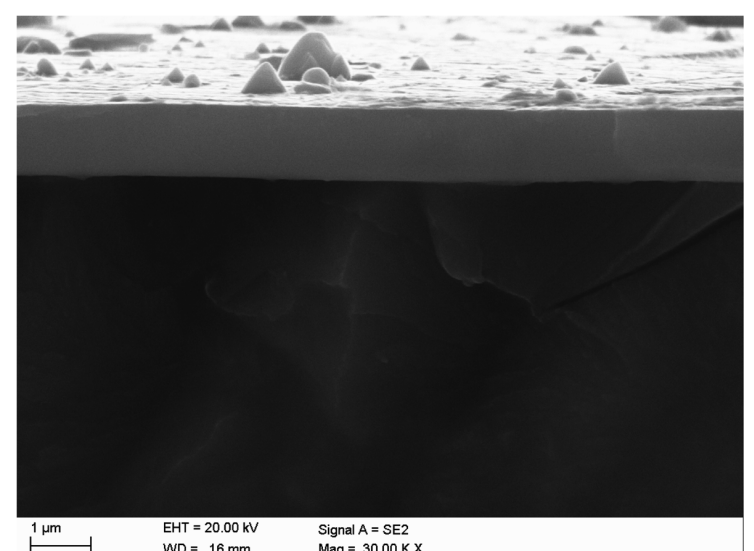

Figure 8: Fracture of $\mathrm{Ti} /(\mathrm{Ti}, \mathrm{Si}) \mathrm{N} /(\mathrm{Ti}, \mathrm{Si}) \mathrm{Nlayer}$ obtained on $\mathrm{MCMgAl}_{6} \mathrm{Zn}_{1}$ cast magnesium alloy

Slika 8: Prelom nanosa Ti/(Ti,Si)N/(Ti,Si)N na $\mathrm{MCMgAl}_{6} \mathrm{Zn}_{1}$ livni magnezijevi zlitini

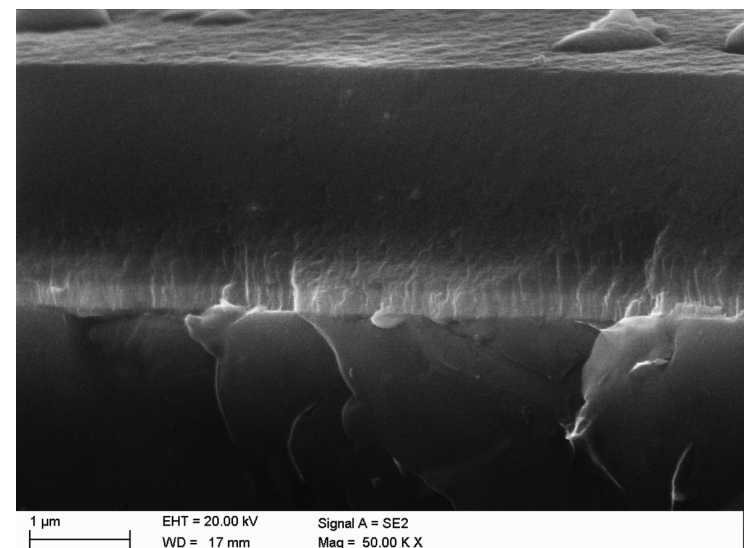

Figure 9: Fracture of Ti/DLC/DLC layer obtained on $\mathrm{AlSi}_{9} \mathrm{Cu}_{1}$ cast aluminum alloy

Slika 9: Prelom nanosa Ti/DLC/DLC na $\mathrm{AlSi}_{9} \mathrm{Cu}_{1}$ livni aluminijevi zlitini

nitride-based layers achieved with the Arc-PVD (Figure 10).

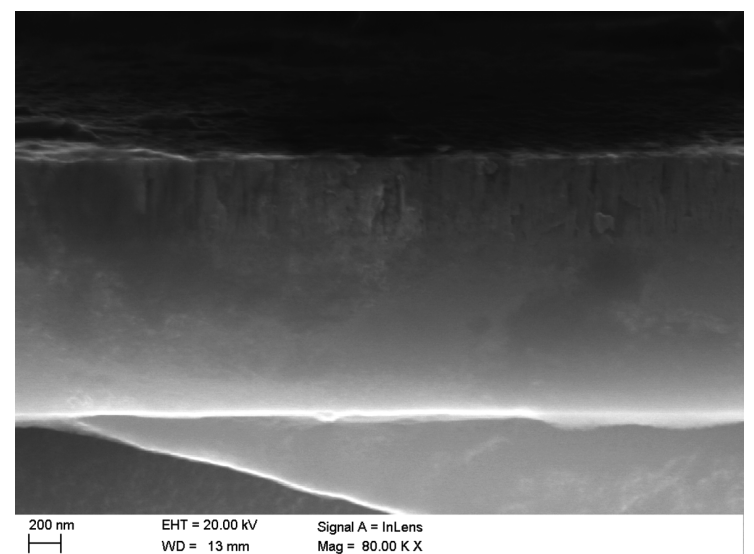

Figure 10: Fracture of $\mathrm{Cr} / \mathrm{CrN} / \mathrm{TiN}$ layer obtained on $\mathrm{MCMgAl}_{9} \mathrm{Zn}_{1}$ cast magnesium alloy

Slika 10: Prelom nanosa $\mathrm{Cr} / \mathrm{CrN} / \mathrm{TiN}$ na $\mathrm{MCMgAl}{ }_{9} \mathrm{Zn}_{1}$ livni magnezijevi zlitini

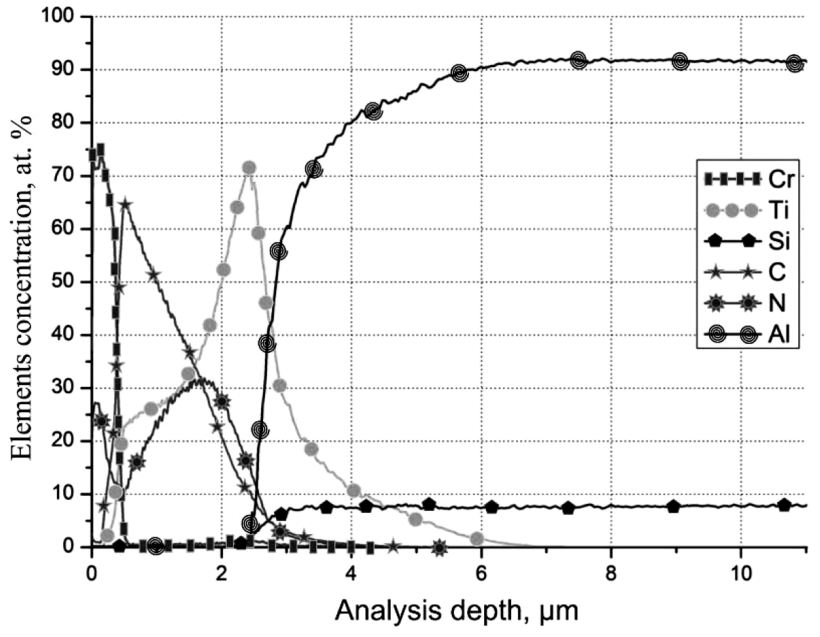

Figure 11: Variation in the concentration of $\mathrm{Ti} / \mathrm{Ti}(\mathrm{C}, \mathrm{N}) / \mathrm{CrN}$ layer chemical elementsobtained on $\mathrm{AlSi}_{9} \mathrm{Cu}_{1}$ magnesium alloy

Slika 11: Spreminjanje koncentracije elementov v $\mathrm{Ti} / \mathrm{Ti}(\mathrm{C}, \mathrm{N}) / \mathrm{CrN}$ nanosu na AlSi9Cu1 magnezijevi zlitini

The chemical-composition investigation carried out with GDOES and SEM confirmed the existence of the chemical elements of the obtained layers in a depth of 1.4-3.4 $\mu \mathrm{m}$ (Figures 11 and 12). The maximum thickness of the layers was measured to beas follows: $\mathrm{Ti} / \mathrm{Ti}(\mathrm{C}, \mathrm{N}) / \mathrm{CrN} \sim 3.3 \mu \mathrm{m} ; \mathrm{Ti} / \mathrm{Ti}(\mathrm{C}, \mathrm{N}) / \mathrm{Ti}(\mathrm{Al}, \mathrm{N}) \sim 3.4 \mu \mathrm{m}$; $\mathrm{Cr} / \mathrm{CrN} / \mathrm{CrN} \sim 1.8 \mu \mathrm{m} ; \mathrm{Cr} / \mathrm{CrN} / \mathrm{TiN} \sim 1.7 \mu \mathrm{m} ; \mathrm{Ti} / \mathrm{Ti}(\mathrm{Si}, \mathrm{N}) /$ $\mathrm{Ti}(\mathrm{Si}, \mathrm{N}) \sim 1.6 \mu \mathrm{m} ; \mathrm{Ti} / \mathrm{DLC} / \mathrm{DLC} \sim 2.5 \mu \mathrm{m}$. The variation in the bonding-zone character - an increase in the chemical-element concentration of the base and a decrease in the chemical-element concentration of the layer - leads to the conclusion about the existence of a transitory diffusion zone between the base material and the layer, which improves their adhesion. Moreover, with the GDOES examination, the decrease zone of the linear concentration of the chemical elements of the layer was

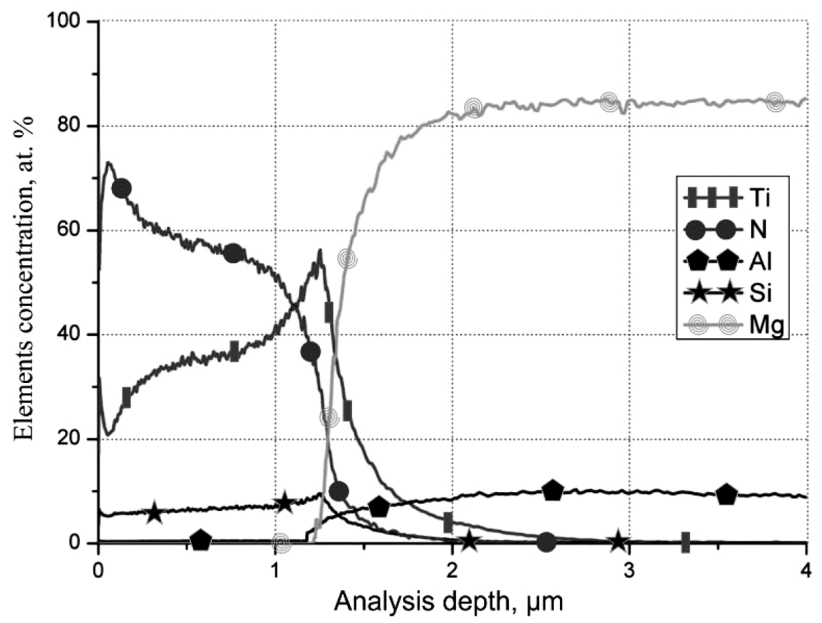

Figure 12: Variation in the concentration of $\mathrm{Ti} /(\mathrm{Ti}, \mathrm{Si}) \mathrm{N} /(\mathrm{Ti}, \mathrm{Si}) \mathrm{N}$ layer chemical elements obtained on $\mathrm{MCMgAl}_{6} \mathrm{Zn}_{1}$ magnesium alloy

Slika 12: Spreminjanje koncentracije elementov v Ti/(Ti,Si)N/ (Ti,Si)N nanosu na MCMgAl6Zn1 magnezijevi zlitini 


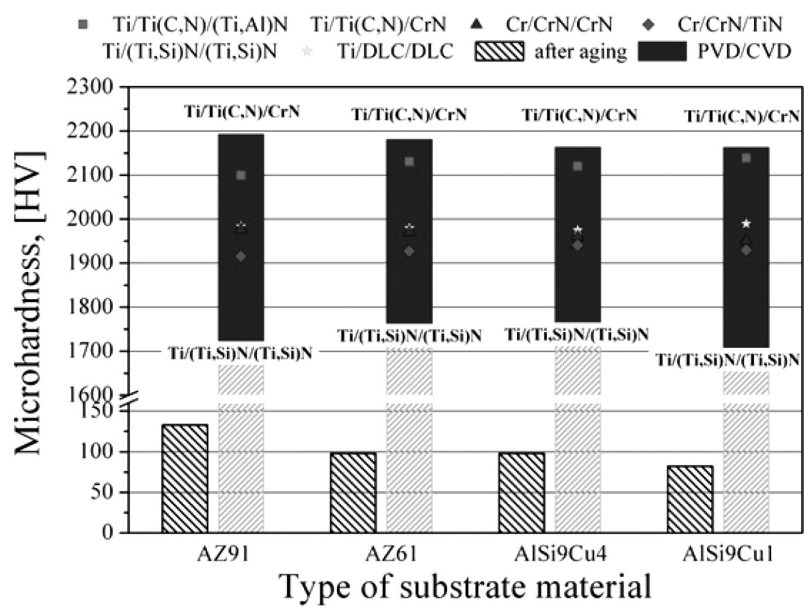

Figure13: Microhardness examination results forcast magnesium $\mathrm{Mg}-\mathrm{Al}-\mathrm{Zn}$ and aluminum Al-Si-Cu alloys after ageing, PVD and CVD processing

Slika 13: Rezultati meritev mikrotrdote na liti magnezijevi Mg-Al-Zn in aluminijevi Al-Si-Cu zlitini, po staranju ter PVD in CVD obdelavi

confirmed - it proves that the layers are gradient (Figures 11 and 12).

The layers obtained with Arc-PVD and PA CVD on the base of $\mathrm{Mg}$ and $\mathrm{Al}$ alloys significantly increased the microhardness compared to the base material (Figure 13). This phenomenon is caused by the chemical- and phase-concentration change, various conditions, the type of the method (PVD or CVD) and the combination of the layers.

The type of base material - Mg or Al alloys - has the least influence on the microhardness (Figure 13). A significant rise in the microhardness after the precipitation hardening, exceeding $100 \%$ compared to the base material, took place due tothe $\mathrm{Cr} / \mathrm{CrN} / \mathrm{CrN}, \mathrm{Cr} / \mathrm{CrN} / \mathrm{TiN}$ and

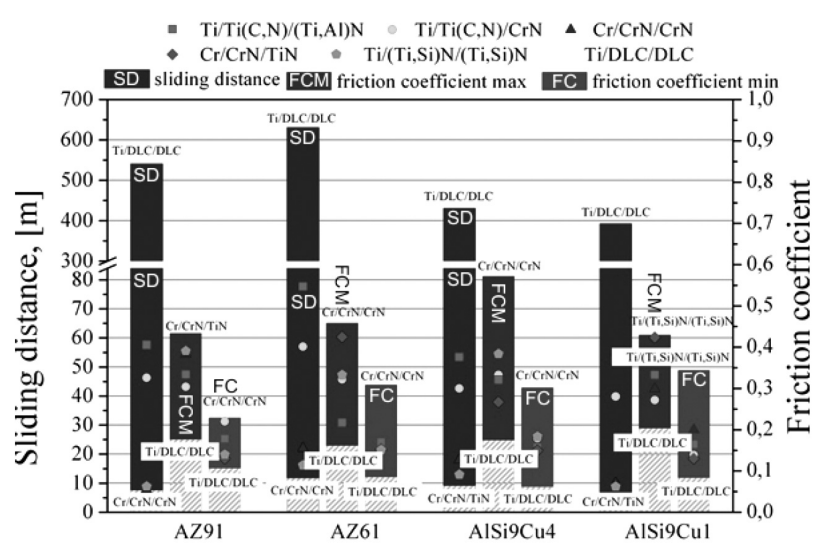

Type of substrate material

Figure14: Dependence of sliding distanceto the coating damage on the minimum and maximum friction coefficients intheball-on-disc test used on PVD and CVD layers obtained on aluminum and magnesium cast alloys

Slika 14: Odvisnost razdalje drsenja do poškodbe nanosa na minimalni in maksimalni koeficient trenja pri preizkusu kroglica na plošči, uporabljenem na PVD in CVD nanosih, na livnih aluminijevih in magnezijevih zlitinah
$\mathrm{Ti} /(\mathrm{Ti}, \mathrm{Si}) \mathrm{N} /(\mathrm{Ti}, \mathrm{Si}) \mathrm{N}$ layers obtained with the cathodic PVD process and $\mathrm{N}_{2}$ as the protective gas. The layers' hardness does not exceed $2000 \mathrm{HV}$ according to the microhardness test results, while the $\mathrm{Ti} / \mathrm{Ti}(\mathrm{C}, \mathrm{N}) / \mathrm{CrN}$ and $\mathrm{Ti} / \mathrm{Ti}(\mathrm{C}, \mathrm{N}) /(\mathrm{Ti}, \mathrm{Al}) \mathrm{N}$ layers obtained within the mixture of $\mathrm{CH}_{4}$ and $\mathrm{N}_{2}$ as the protective gas are even harder than $2000 \mathrm{HV}$.

In the case of the $5 \mathrm{~N}$ load used in the examination, the average friction factor for theDLC coatings (done on $\mathrm{Al}$ and $\mathrm{Mg}$ ) achieved with a $0.05 \mathrm{~m} / \mathrm{s}$ slide velocity is in a range of 0.06-0.16 (Figure 15). Thisis a decrease in the whole order of magnitude in comparison to the other layers. This state is characteristic for the DLC layers that consist of graphite, which works like a lubricant during the abrasion process. Moreover, a high traverse speed, which causes heat accumulation, is responsible for an easier self-lubrication of the layer, resulting in a reduction in the friction coefficient (Figures 14 and 15). The sliding distance for the DLC coatings obtained on $\mathrm{Mg}$ is even 70 times higher than those measured for $\mathrm{Cr} / \mathrm{CrN} /$ $\mathrm{CrN}$ or diamond-like layers (Figure 14). The sliding-distance values for all the examined layers were in a range of 6-630 $\mathrm{m}$ (Figure 14). When examining all the ball-on-disk test results, it was confirmed that the value
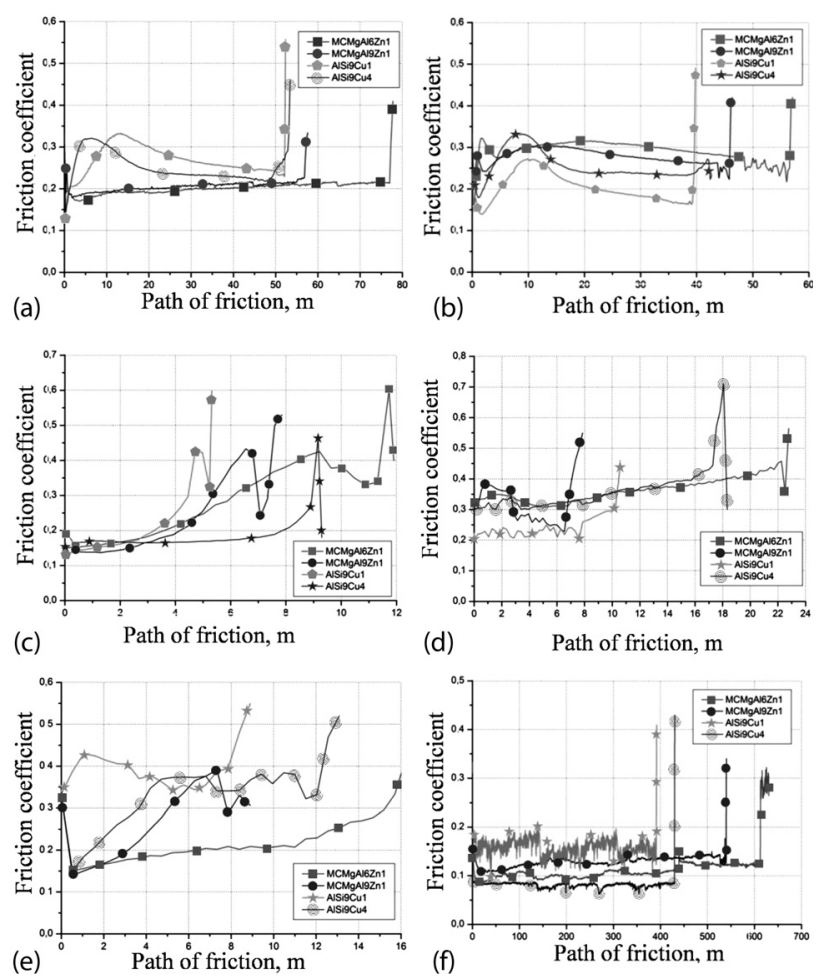

Figure 15: Dependence of layer friction coefficient on the counter-samplesliding distance achieved withtheball-on-disc method on: a) $\mathrm{Ti} /(\mathrm{Ti}(\mathrm{C}, \mathrm{N}) /(\mathrm{Ti}, \mathrm{Al}) \mathrm{N}, \quad$ b) $\mathrm{Ti} /(\mathrm{Ti}(\mathrm{C}, \mathrm{N}) / \mathrm{CrN}, \quad$ c) $\mathrm{Cr} / \mathrm{CrN} / \mathrm{TiN}, \quad \mathrm{d})$ $\mathrm{Cr} / \mathrm{CrN} / \mathrm{CrN}$, e) $\mathrm{Ti} /(\mathrm{Ti}, \mathrm{Si}) \mathrm{N} /(\mathrm{Ti}, \mathrm{Si}) \mathrm{N}, \mathrm{f}) \mathrm{Ti} / \mathrm{DLC} / \mathrm{DLC}$, obtained on aluminum and magnesium cast alloys

Slika 15: Odvisnost koeficienta trenja od razdalje drsenja, dobljene pri metodi kroglica na plošči pri: a) $\mathrm{Ti} /(\mathrm{Ti}(\mathrm{C}, \mathrm{N}) /(\mathrm{Ti}, \mathrm{Al}) \mathrm{N}$, b) Ti/ ( $\mathrm{Ti}(\mathrm{C}, \mathrm{N}) / \mathrm{CrN}$, c) $\mathrm{Cr} / \mathrm{CrN} / \mathrm{TiN}$, d) $\mathrm{Cr} / \mathrm{CrN} / \mathrm{CrN}$, e) $\mathrm{Ti} /(\mathrm{Ti}, \mathrm{Si}) \mathrm{N} /(\mathrm{Ti}, \mathrm{Si}) \mathrm{N}$, f) $\mathrm{Ti} / \mathrm{DLC} / \mathrm{DLC}$ na livnih aluminijevih in magnezijevih zlitinah 
of the sliding distance for magnesium coatings is larger than the sliding distance obtained with the aluminum-layer dual system; moreover, the results for the DLC coatings are even $30 \%$ better (Figure 14).

For the tribological-resistance examination of the obtained layers, the charts demonstrating the rotation quantity or displacement of the countersample before the coating damage, depending on the friction coefficient and/or displacement of the countersample along the vertical axis were created. For all the registered friction coefficients dependingon the rotation quantity or the sliding distance, similar characteristic curves, which can be divided into two parts, were determined (Figure 15). In the first part, a significant increase in the friction coefficient with the sliding-distance increase was determined. It was accepted that it is the transient friction state. The second part of the chart is similar to the stationary state. Large changes in the friction coefficient measured during the examination were caused by a spallation of the sample and counter-sample surfaces.

\section{CONCLUSION}

Gradient and monolithic coatings including $\mathrm{Ti} / \mathrm{Ti}(\mathrm{C}, \mathrm{N}) / \mathrm{CrN}, \quad \mathrm{Ti} / \mathrm{Ti}(\mathrm{C}, \mathrm{N}) /(\mathrm{Ti}, \mathrm{Al}) \mathrm{N}, \quad \mathrm{Ti} /(\mathrm{Ti}, \mathrm{Si}) \mathrm{N} /$ (Ti,Si)N, Cr/CrN/CrN, Cr/CrN/TiN and Ti/DLC/DLC were successfully deposited onto magnesium- and aluminum-alloy substrates using the cathodic-arc-evaporation method (Arc-PVD) and plasma-assisted process (PA CVD). The layers obtained with Arc-PVD and PA CVD on the base of $\mathrm{Mg}$ and $\mathrm{Al}$ alloys significantly increased the microhardness compared to the base material. The type of base material had the least influence on the microhardness. The fracture morphology was characterized by a lack of columnar structures in the obtained coatings. The metallographic examinations proved that the coatings were deposited uniformly over the whole sample onto the investigated substrate materials and that the measured thickness was characteristic for this coating type. It was also found that individual layers adhered tightly to each other and to the light metal substrate. The average friction factor of the DLC coatings (on $\mathrm{Al}$ and $\mathrm{Mg}$ ) achieved at a $0.05 \mathrm{~m} / \mathrm{s}$ slide velocity was in a range of $0.06-0.16$, which was a decrease in the whole order of magnitude in comparison to the other layers. Examining all the ball-on-disk test results, it was confirmed that the value of the sliding distance for the magnesium coatings was higher than the sliding distance obtained with the aluminum-layer dual system; moreover, the results for the DLC coatings were even $30 \%$ better. The investigation results obtained for the PVD method make it possible to obtain interesting solutions, which are very promising for the use in the automobile and aviation industries, for the production of the elements whose high functional properties like hardness and wear resistance are crucial for long-term service.

\section{Acknowledgements}

This publication was co-financed within the framework of the statutory financial grant providedby the Faculty of Mechanical Engineering of the Silesian University of Technology in 2015 .

\section{REFERENCES}

${ }^{1}$ M. Avedesian, H. Baker (Eds.), ASM Specialty Handbook: Aluminium and Aluminium Alloys, ASM International, The Materials Information Society, USA 1999

${ }^{2}$ E. F. Horst, B. L. Mordike, Magnesium Technology, Metallurgy, Design Data, Application, Springer-Verlag Berlin, Heidelberg 2006

${ }^{3}$ T. Tański, A. D. Dobrzańska-Danikiewicz, K. Labisz, W. Matysiak, Long-term development perspectives of selected groups of engineering materials used in the automotive industry, Archives of Metallurgy and Materials, 59 (2014) 4, 1729-1740, doi:10.2478/amm-20140290

${ }^{4}$ M. Mattox, Handbook of Physical Vapor Deposition (PVD) Processing, Elsevier Science, <kraj izida manjka>2010

${ }^{5}$ L. Zeng, S. Yang, W. Zhang, Y. Guo, Ch. Yan, Preparation and characterization of a double-layer coating on magnesium alloy AZ91D, Electrochimica Acta, 55 (2010), 3376-3383, doi:10.1016/j.electacta. 2010.01.041

${ }^{6}$ K. Mao, Y. Sun, A. Bloyce, T. Bell, Surface coating effects on contact stress and wear: an approach of surface engineering design and modelling, Surface Engineering, 26 (2010) 1-2, 142-148, doi:10.1179/174329409X446313

${ }^{7}$ M. Pellizzari, High temperature wear and friction behaviour of nitrided, PVD-duplex and CVD coated tool steel against $6082 \mathrm{Al}$ alloy, Wear, 271 (2011), 2089-2099, doi:10.1016/j.wear.2011.01.067

${ }^{8}$ J. Eriksson, M. Olsson, Tribological testing of commercial $\mathrm{CrN}$, (Ti,Al)N and CrC/C PVD coatings - Evaluation of galling and wear characteristics against different high strength steels, Surface and Coatings Technology, 205 (2011), 4045-4051, doi:10.1016/ j.surfcoat.2011.02.053

${ }^{9}$ I. Endler, M. Höhn, M. Herrmann, H. Holzschuh, R. Pitonak, S. Ruppi, H. van den Berg, H. Westphal, L. Wilde, Aluminum-rich TiAlCN coatings by low pressure CVD, Surface and Coatings Technology, 205 (2010), 1307-1312, doi:10.1016/j.surfcoat.2010.09.002

${ }^{10}$ L. A. Dobrzański, L. W. Żukowska, J. Mikuła, K. Gołombek, D. Pakuła, M. Pancielejko, Structure and mechanical properties of gradient PVD coatings, Journal of Materials Processing Technology, 201 (2008) 1-3, 310-314, doi:10.1016/j.jmatprotec.2007.11.283

${ }^{11}$ K. Lukaszkowicz, J. Sondor, K. Balin, J. Kubacki, Characteristics of CrAlSiN + DLC coating deposited by lateral rotating cathode arc PVD and PACVD process, Applied Surface Science, 312 (2014) 1, 126-133, doi:10.1016/j.apsusc.2014.03.024

${ }^{12}$ M. W. Richert, A. Mazurkiewicz, J. A. Smolik, The deposition of WC-Co coatings by EBPVD technique, Archives of Metallurgy and Materials, 57 (2012) 2, 511-516, doi:10.2478/v10172-012-0053-0

${ }^{13}$ W. Gebarowski, S. Pietrzyk, Influence of the cathodic pulse on the formation and morphology of oxide coatings on aluminium produced by plasma electrolytic oxidation, Archives of Metallurgy and Materials, 58 (2013) 1, 241-245, doi:10.2478/v10172-012-0180-7

${ }^{14}$ G. R. dos Santos, D. D. da Costa, F. L. Amorim, R. D. Torres, Characterization of DLC thin film and evaluation of machining forces using coated inserts in turning of Al-Si alloys, Surface and Coatings Technology, 202 (2007), 1029-1033, doi:10.1016/j.surfcoat.2007. 07.100

${ }^{15}$ Q. Wang, F. Zhou, Z. Zhou, Y. Yang, C. Yan, C. Wang, W. Zhang, L. Kwok-Yan Li, I. Bello, S. Tong Lee, Influence of Ti content on the structure and tribological properties of Ti-DLC coatings in water lubrication, Diamond \& Related Materials, 25 (2012), 163-175, doi:10.1016/j.diamond.2012.03.005 


\section{T. TAŃSKI et al.: SURFACE TREATMENT OF HEAT-TREATED CAST MAGNESIUM AND ALUMINIUM ALLOYS}

${ }^{16}$ Y. S. Zou, Y. F. Wu, H. Yang, K. Cang, G. H. Song, Z. X. Li, K. Zhou, The microstructure, mechanical and friction properties of protective diamond like carbon films on magnesium alloy, Applied Surface Science, 258 (2011), 1624-1629, doi:10.1016/j.apsusc.2011. 10.031

${ }^{17}$ J. Smolik, J. Walkowicz, T. Szubrycht, Ellipsometric characteristics of diamond-like a-C:H films obtained by the r.f. PACVD method, Surface and Coatings Technology, 174-175 (2003), 345-350, doi:10.1016/S0257-8972(03)00373-6

${ }^{18}$ T. Tański, Characteristics of hard coatings on AZ61 magnesium alloys, Journal of Mechanical Engineering, 59 (2013) 3, 165-174, doi:10.5545/sv-jme.2012.522
${ }^{19}$ T. Tański, K. Labisz, K. Lukaszkowicz, A. Śliwa, K. Gołombek, Characterisation and properties of hybrid coatings deposited onto magnesium alloys, Surface Engineering, 30 (2014) 12, 927-932, doi:10.1179/1743294413Y.0000000194

${ }^{20}$ M. Staszuk, L. A. Dobrzański, T. Tański, W. Kwaśny, M. Musztyfaga, The effect of PVD and CVD coating structures on the durability of sintered cutting edges, Archives of Metallurgy and Materials, 59 (2014) 1, 269-274, doi:10.2478/amm-2014-0044 